\title{
Two steps forward, one step back: reflections on the jurisprudential turn of the Inter- American Court of Human Rights on domestic reparation programmes
}

\author{
By Clara Sandoval ${ }^{1}$ \\ School of Law/Human Rights Centre, University of Essex, UK
}

\begin{abstract}
This article is a contribution to an area of research that remains neglected in both the literature on reparations under international law and on the jurisprudence of the InterAmerican Court of Human Rights: the co-existence of reparation regimens at the international and domestic level and the problems this creates. In particular, it reflects on the jurisprudential turn of the Inter-American Court in the area of reparations as a result of considering allegations regarding Domestic Reparations Programmes (DRPs) in states undergoing transitions, particularly Chile, Colombia, Guatemala and Peru. In addition to considering the role of subsidiarity in the most recent jurisprudence of the court, it addresses three questions: Why has the Inter-American Court tried to reconcile the co-existence of these reparation's systems? How has it done so? And, what are the consequences of this jurisprudential turn for international law and for the institutional design of the Inter-American System?
\end{abstract}

Keywords: Inter-American Court of Human Rights; reparations; subsidiarity; domestic reparation programmes; transitional justice.

\section{Introduction}

The Inter-American Human Rights System (IAHRS), comprised of both a Commission and Court, has contributed in a significant way to the development of the field of transitional justice and of various institutions of international human right law and international criminal law. ${ }^{2}$ Indeed, its jurisprudence has made unique contributions to the right to justice, the right to know the truth, and the right to reparation, and it has helped to flesh out their content and their reach. In particular, the System has crafted the most comprehensive and holistic approach to reparations under international human rights law. ${ }^{3}$

The Court has tried to address the various harms suffered by victims of human rights violations through a victim-sensitive approach to reparations that includes a flexible concept

\footnotetext{
${ }^{1}$ Clara Sandoval is a Senior Lecturer at the School of Law and member of the Human Rights Centre at the University of Essex and Director of the Essex Transitional Justice Network. E-mail: csando@essex.ac.uk This article benefited from the comments I received from various people. I am particularly grateful for the great feedback I received from the anonymous reviewers, Courtney Hillebrecht, Michael Duttwiler, Sabine Michalowski and Paola Limon, and from those present at the II Leverhulme Inter-American Human Rights Network Workshop at University College London in October 2015.

${ }^{2}$ For example, J P Perez-Leon, 'The Emerging Reparations Case-Law of the ICC Appeals Chamber in Comparative Perspective' in EJIL: Talk 12 June 2015, available at: http://www.ejiltalk.org/category/international-tribunals/inter-american-court-of-human-rights/ ${ }^{3}$ Dinah Shelton, Remedies in International Human Rights Law (Oxford: Oxford University Press, $2^{\text {nd }}$ edition, 2005), p. 299.
} 
of 'victim', a similarly flexible approach to the standard and burden of proof, and the use of different forms of reparation that go beyond compensation and restitution such as satisfaction, rehabilitation and guarantees of non-repetition. The Court has crafted such an interpretation of the right to reparation based on Article 63.1 of the American Convention, that reads:

'If the Court finds that there has been a violation of a right or freedom protected by this Convention, the Court shall rule that the injured party be ensured the enjoyment of his right or freedom that was violated. It shall also rule, if appropriate, that the consequences of the measure or situation that constituted the breach of such right or freedom be remedied and that fair compensation be paid to the injured party'.

An example of this holistic approach to reparations is the judgment on reparations in the case of Massacre of Plan de Sanchez $v$ Guatemala. ${ }^{5}$ In this case, military personnel, informants and civil patrol members killed, displaced, tortured and committed other human rights violations against hundreds of Maya-Achi members in 1982. The state also failed to carry out a diligent investigation into the violations. ${ }^{6}$ The Court used a flexible concept of who could qualify as victim, considering that those unable to prove their identity could also classify as victims if certain requirements were met; ${ }^{7}$ decided many of the reparations based on fairness or presumptions; ${ }^{8}$ and used different forms of reparation to wipe out the harm suffered. It awarded $\$ 5,000$ for pecuniary damages and $\$ 20,000$ for non-pecuniary damages per victim, ${ }^{9}$ and ordered Guatemala: to investigate the case with due diligence ${ }^{10}$ to translate the judgment to Maya-Achi; ${ }^{11}$ to publish parts of the Judgment in national newspapers; ${ }^{12}$ to give $\$ 25,000$ to the community to honour the memory of the victims; ${ }^{13}$ to carry out a housing and a development programme for the survivors that should include a sewage system and potable water ${ }^{14}$ and to provide survivors with medical and psychological treatment. ${ }^{15}$ According to Thomas Antkowiak 'This was the first time any international tribunal ordered reparations for the survivors and next of kin of a full-scale massacre. The breadth and depth of the remedies orders are impressive. ${ }^{, 16}$

This holistic jurisprudence on reparation has been applied by the Court in the majority of its judgments, but during the last decade a jurisprudential turn began to take place as the Court had to resolve cases involving the right to reparation in Domestic Reparation Programmes (DRPs). DRPs are domestic executive or legislative initiatives which identify a group of

\footnotetext{
${ }^{4}$ OAS General Assembly, American Convention on Human Rights, OAS Treaty Series, No. 36, 22 November 1969, entry into force on 18 July 1978.

${ }^{5}$ Inter-American Court of Human Rights, Plan de Sanchez v Guatemala, judgment on the merits, 29 April 2004.

${ }^{6}$ Ibid.

${ }^{7}$ Ibid, [62], [676] and [686].

${ }^{8}$ Ibid, [74] and [88].

${ }^{9}$ Ibid, [74-76] and [88-89].

${ }^{10}$ Ibid, [94-99].

${ }^{11}$ Ibid, [102].

${ }^{12}$ Ibid, [103].

${ }^{13}$ Ibid, [104].

${ }^{14}$ Ibid, [105] and [109-111].

${ }^{15}$ Ibid, [106-108].

${ }^{16}$ Thomas M. Antkowiak, 'Remedial Approaches to Human Rights Violations: The Inter-American Court of Human Rights and Beyond' (2008) 46(2) Columbia Journal of Transnational Law 351, 371.
} 
victims as beneficiaries of reparation and then provide them with redress, usually through similar reparation measures; a summary and fast process; and without the legal costs and high burden and standard of proof required in a judicial setting. ${ }^{17}$

In times of transition from repression to democracy or from conflict to peace, a DRP has become the natural tool to provide redress to victims of gross human rights violations or serious violations of humanitarian law. In countries where massive and gross human rights violations have taken place during periods of repression or conflict, as has been the case in various Organisation of American States (OAS) members including Argentina, Guatemala, Chile, Colombia and El Salvador, it is not possible or adequate to deal with reparations for such violations through the judiciary. Put simply, the courts are unable to deal with hundreds of thousands, if not millions, of claims for reparation, and victims do not have the time or the money to claim their right before the courts. Therefore, DRPs constitute an important tool in providing prompt and effective redress to victims.

For example, in a country like Colombia, with more than seven million victims of the internal armed conflict, ${ }^{18}$ a DRP was established through the enactment of the Victims and Land Restitution Law (Ley 1448/2011) ${ }^{19}$ which provided reparations to individual or collective victims who were subjected to violations such as, killings, internal displacement, sexual violence, torture, kidnapping, land destitution and disappearances, on or after 1 January 1985. To claim reparation, victims needed to register in the National Registry of Victims and to render a declaration indicating how they were victimised within the timeframe established in the Law. The DRP includes all forms of reparation: restitution (including land restitution), compensation, rehabilitation, satisfaction and guarantees of non-repetition.

During the first years of the Inter-American Court's work, states failed to take seriously the right to redress for victims. Therefore, the Court, in application of the principle of complementarity, was prompted to provide reparations to victims as part of its adjudication mandate, thereby crafting its holistic jurisprudence. However, as awareness of this right began to grow among OAS member states, they began to take measures at the domestic level to try and redress the harm they had caused by action or omission when human rights violations were at stake, either through reparations ordered by courts or through reparations given to victims as part of a DRP.

The consequence of the change in state behaviour is that DRPs do not follow the standards set by the Inter-American Court on reparations, and the Court has been asked to adjudicate on such issues. For some OAS member States this is seen as an invasion of their own sovereignty, given the subsidiary nature of the Court and the effect that the Court's views can have during a transition to peace or democracy.

For example, the Inter-American Court almost always awards compensation for harm done, as seen in Massacre of Plan de Sanchez where the Court awarded both pecuniary and non-

\footnotetext{
${ }^{17}$ Rashida Manjoo, Report of the Special Rapporteur on violence against women, its causes and consequences, A/HRC/14/22, 19 April 2010.

${ }^{18}$ According to the Colombian National Registry of Victims, there are 7,844,527 victims of the internal armed conflict in Colombia of whom 6,230,919 are entitled to reparations through the DRP. See http://rni.unidadvictimas.gov.co/RUV consulted on 22 August 2016.

${ }^{19}$ Colombian Congress, Ley de Victimas y Restitucion de Tierras, Ley 1448/2011, available at: http://www.unidadvictimas.gov.co/es/ley-1448-de-2014-ley-de-v\%C3\%ADctimas/9022
} 
pecuniary damages. Providing compensation in DRPs, in application of the same standards followed by the Inter-American Court, could be incredibly costly as DRPs are dealing with a potentially vast number of victims. For example, to provide redress in Plan de Sanchez, just one of the 626 massacres carried out by members of the military and documented by the Truth Commission in Guatemala, ${ }^{20}$ the state had to pay $\$ 7.9$ million. ${ }^{21}$ Therefore, states are either unable or unwilling to replicate the jurisprudence of the Inter-American Court via DRPs.

This article looks at the change in the approach of the Inter-American Court, as a result of the tension that has grown between its own reparation standards and those applied by DRPs in the region. ${ }^{22}$ This tension can be analysed from different perspectives. In this article, however, a socio-legal approach is followed. This article is unique in that it does not aim to explain the jurisprudential turn from a strictly legal point of view, but rather bears in mind the political and economic context that has surrounded the Court when adjudicating on this issue. In particular, the article addresses three issues: why the Inter-American Court has tried to reconcile the co-existence of these reparation's systems; how it has done so; and what the consequences of this jurisprudential turn are. The article shows how the Inter-American Court has relied on the subsidiarity principle either to avoid dealing with the tension or to resolve it. The article also reflects on the implications of this jurisprudential turn for the fulfilment of the right to reparation in OAS member states and beyond the region. The current approach of the Court threatens its own reparation standards and leaves victims without an adequate and effective remedy, at the international level, to protect their right to reparation.

\section{Why the Inter-American Court has tried to reconcile the co-existence of the reparation systems?}

Various reasons explain why the Court has been forced to reconcile the co-existence of DRPs with its own reparation standards. The Inter-American Court does not exist in a vacuum, but in a political, financial and cultural context, where states exert pressure to protect their interests. This growing pressure on the IAHRS has forced the Court to reconcile its approach to reparations with those of DRPs. Against judgments on reparations, such as that of Plan de Sanchez, states have argued financial difficulties in paying the Court's orders, and have requested that the tribunal allow them to offer redress to the victims through DRPs. ${ }^{23}$

Other states, such as Peru, have felt that the Court was ordering reparations for people the state viewed as terrorists: President Humala expressly declared 'my government will not pay

\footnotetext{
${ }^{20}$ Comisión de Esclarecimiento Histórico, Guatemala Memoria del Silencio, Conclusiones y Recomendaciones, (Guatemala, June 1999) [86].

${ }^{21}$ Naomi Roht-Arriaza and Marci Mersky, 'Guatemala', in Victims Unsilenced: The Inter-American Human Rights System ad Transitional Justice in Latin America (Washington: Due Process of Law Foundation, 2007), p. 19.

${ }^{22}$ The difficult co-existence between decisions on reparations by the judiciary at the domestic level and the Inter-American Court's law on reparations is not addressed in this article but it does take place. An important case to be studied in this regard is that of decisions by the Colombian judiciary on reparations for victims of the armed conflict.

${ }^{23}$ Presidencia de la Republica, COPREDEH, 21 May 2004, RED-A-28-2004, point 7, p. 15 or Presidencia de la Republica, Comision Presidencial Coordinadora de la Politica del Ejecutivo en Materia de Derechos Humanos COPEDEH, Alegatos Finales del Estado de Guatemala dentro del Caso 12.599 Florencio Chitay vs. Guatemala, Presentado ante la Honorable Corte Interamericana de Derechos Humanos, 3 de marzo de 2010, p. 6 and 10 and Inter-American Court of Human Rights, Omar Humberto Maldonado Vargas et al. $v$ Chile, judgment on merits, reparations and costs, 2 September 2015 [173].
} 
one Sol in compensation in favour of terrorists and relatives even if that is ordered by the Inter-American Court'. ${ }^{24}$ Such a statement has to be read whilst bearing in mind that the DRP in Peru deems that rebels are not entitled to reparations, so the Inter-American Court should not go against its DRP standards. ${ }^{25}$

Pressure is not the only reason why the Court has had to reconcile its standards with those of DRPs. A more worrying issue for the Court is the lack of implementation of its orders if states consider them to be in breach of their own DRP standards. Problems with the implementation of orders by the Court and the Commission are well known. ${ }^{26}$ The risk is that they can be accentuated if the Court is not sensitive to transitional justice processes and DRPs. A good example of this risk was the position taken by Guatemala during the Presidency of Otto Perez Molina, refusing to comply with the orders of the Court as they were, among other reasons, in breach of their own DRP standards. ${ }^{27}$

Another important reason why the Court has had to reconcile its principles with those of DRPs is the change in the nature of the litigation carried out before the Commission and the Court. For many years, in litigation before the Court, the legal representatives of the victims did not refer to the DRPs in their pleadings. They were perhaps unaware of the right to reparation, had a different objective with the litigation, ${ }^{28}$ the Court had no temporal jurisdiction over the matter, ${ }^{29}$ or the argument was irrelevant given that states were not referring to DRPs in their legal arguments. Indeed, up until a decade ago, it could be taken for granted that the Court would continue to award its holistic and victim-centred reparations. ${ }^{30}$

After this time, the nature of the litigation began to change when the legal representatives of the victims or the states' representatives attacked or referred to the DRPs in their pleadings, as awareness on the right to reparation grew, and as the four 'pillars' of transitional justice (reparation, justice, truth and guarantees of non-repetition) began to be known and used to

\footnotetext{
${ }^{24}$ RPP Noticias, 'Humala sobre Chavín de Huántar: No Voy a Dar ni un Sol a los Terroristas', 26 June 2015, available at: http://rpp.pe/politica/actualidad/humala-sobre-chavin-de-huantar-no-voy-a-dar-ni-un-sol-a-losterroristas-noticia-811351 See also Correo, 'Gustavo Adrianzan: No Pagaremos a Terroristas ni ONG que los Patrocinan', 28 June 2015, available at: http://diariocorreo.pe/politica/gustavo-adrianzen-no-pagaremos-aterroristas-ni-ong-que-los-patrocinan-598046/

${ }^{25}$ Plan Integral de Reparaciones, Ley 28592, Ley que crea el programa integral de reparaciones - PIR, Article 4, available at: http://www.acnur.org/t3/fileadmin/Documentos/BDL/2012/8868.pdf?view=1

${ }^{26}$ Consejo Permanente de la Organisación de los Estados Americanos, Comisión de Asuntos Jurídicos y Políticos, 'Informe de la Secretaria sobre el dialogo sobre el funcionamiento del sistema interamericano de derechos humanos entre los estados miembros y los miembros de la comisión interamericana de derechos humanos y de la corte interamericana de derechos humanos,' OEA/Ser.G CP/CAJP-3002/11, 13 May 2011, p.45 and Ariel Dulitzky, 2011 'The Inter-American Human Rights System Fifty Years Later: Time for Changes', Quebec Journal of International Law 127 (2011): 138.

${ }^{27}$ Inter-American Court of Human Rights, Resolution, Monitoring Compliance in Rio Negro and Gudiel Alvarez v Guatemala, 21 August 2014, paras. 2-18.

${ }^{28}$ In Almonacid Arellano $v$ Chile, for example, in a case litigated before the IAHRS near the time of the adoption of the Basic Principles and Guidelines on the right to a remedy (2005), and decided by the Court in 2006, the focus of the litigation was on the lack of due diligence in the investigation of the killing of $\mathrm{Mr}$. Almonacid and not on reparations. The next of kin felt that they had already obtained redress from the state regardless of whether such redress was adequate, prompt and effective, and explicitly stated that it is not in the interest of Mr. Almonacid-Arellano's next of kin to obtain pecuniary benefits.' Inter-American Court of Human Rights, Almonacid Arellano et al. $v$ Chile, judgment on preliminary objections, merits, reparations and costs, 26 September 2006.

${ }^{29}$ As happened with the atrocities that occurred in Argentina during Videla's dictatorship.

${ }^{30}$ Thomas Antkowiak, 'An Emerging Mandate for International Courts: Victim-Centered Remedies and Restorative Justice’ (2011) 47 Stanford Journal of International Law 279.
} 
protect human rights. This forced the Court to address the arguments of the parties and to take a position in relation to them in relation to four OAS member states: Colombia, Guatemala, Chile and, lately, Peru.

\section{How the Court has reconciled the co-existence}

This section illustrates the shifts of the Court's jurisprudence regarding DRPs and urges the Court to develop a legally reasoned and defensible approach to whether DRPs stand scrutiny against the Inter-American standards on reparation. There is no logical chronological procession in the Court's approach to DRPs, although up until Garcia Lucero (2013), the Court defended its own standards on reparation more; since then it has had a tendency to apply the subsidiarity principle on occasions where it appears to be persuaded that DRPs are effective for victims to obtain redress.

\section{From a holistic approach to reparations to subsidiarity in relation to DRPs}

This article looks at the four DRPs that have been the object of adjudication by the InterAmerican Court: Chile, Colombia, Guatemala and Peru. In each of these countries DRPs have been designed and put in place to redress an almost immeasurable number of victims. In Guatemala the Programa Nacional de Resarcimiento (PNR) was established in $2003 .^{31}$ It includes various forms of redress, including collective reparations. The programme has faced serious implementation obstacles, such as the lack of financial resources to provide reparations, and the lack of a national registry of victims of the armed conflict. ${ }^{32}$ In the case of Chile, assorted forms of redress have been incorporated in various laws that have been enacted to provide reparation to Pinochet's victims. ${ }^{33}$ This DRP is seen to be highly successful as it has been able to reach many victims. ${ }^{34}$ In Peru, a DRP was established through Law No. 28592/2005, to redress victims of the armed conflict between 1980 and $2000^{35}$ and includes both individual and collective reparations. ${ }^{36}$ The DRP most recently established in the region is the Colombian Victims and Land Restitution Law, ${ }^{37}$ enacted in 2011 and intended to redress more than 7 million victims. ${ }^{38}$

\footnotetext{
${ }^{31}$ The PNR was established in Guatemala by Acuerdo Gubernativo 258-2003 (not a law), and has been reformed by other Acuerdos Gubernativos such as 539-2013.

${ }^{32}$ Impunity Watch, Monitoreo de la Justicia Transicional en Guatemala, Vol. III, Derecho a la Reparación para las Víctimas del Conflicto Armado Interno, 2014, available at: http://www.impunitywatch.org/docs/Tomo_IIIcompressed.pdf, P. 31 .

${ }^{33}$ Congreso Nacional, Ley No. 19.123 of 8 de febrero de 1992, por la que se crea la Corporación Nacional de Reparación y Reconciliación, Establece Pensión de Reparación y Otorga otros Beneficios en Favor de Personas que Señala, available at: http://www.ddhh.gov.cl/filesapp/Ley_19123.pdf

${ }^{34}$ Elisabeth Lira, 'The Reparations Policy for Human Rights Violations in Chile' in Pablo de Greiff (ed.) The Handbook of Reparations (Oxford, Oxford University Press, 2005), pp. 55-101.

${ }^{35}$ National Congress of Peru, Ley 28592 de 29 de Julio de 2005, Ley que Crea el Plan Integral de Reparaciones PIR.

${ }^{36}$ International Center for Transitional Justice, Reparaciones en Peru: El Largo Camino entre las Recomendaciones y la Implementacion, June 2013.

${ }^{37}$ Congreso de la Republica, Ley 1448 de 2011, por la cual se dictan medidas de atención, asistencia y reparación integral a las víctimas del conflicto armado interno y se dictan otras disposiciones, 10 June 2011, available at: http://www.justiciatransicional.gov.co/sites/default/files/LEY-1448-DE-2011-LEY-DEVICTIMAS-DIARIO-OFICIAL.pdf

${ }^{38}$ Harvard Kennedy School Carr Center for Human Rights Policy, Reparaciones Integrales en Colombia: Logros y Desafios: Evaluacion Comparativa y Global, Draft 24 October 2014, available at:
} 
At the same time that these states have taken important transitional justice measures to deal with the atrocities of the past, victims have not always been able to achieve justice at the domestic level, turning instead to the Inter-American System so that the violations they have suffered in any of these countries are recognised and redressed. The following analysis presents four approaches that can be discerned from the jurisprudence of the Inter-American Court.

\section{The Court disregards DRPs and reiterates its holistic reparations jurisprudence}

In the early years of the new century, the Court was beginning to be recognised for its significant contribution to the right to reparation under international law. By then it had decided cases such as, Garrido $v$ Argentina, ${ }^{39}$ Loayza Tamayo $v$ Peru ${ }^{40}$ and Cantoral Benavides $v$ Peru ${ }^{41}$ and, as Antkowiak remarks, 'the Court unleashed a barrage of reparations judgments in 2001, ten in total, nearly doubling it jurisprudence on the subject'. ${ }^{42}$. This created momentum for the Court to disregard incipient arguments appealing to DRPs. This was also possible given that states were not attacking its approach to reparations.

In this context, states like Peru and Guatemala began to refer to their DRPs in the arguments presented before the Court. According to the arguments, the Court should allow them to redress victims using their own DRPs instead of ordering competing forms of redress. This was the case in Castro Castro Prison v Peru, ${ }^{43}$ and in Plan de Sanchez v Guatemala where Guatemala recognised international responsibility for multiple violations of the American Convention, but, argued that reparations ordered by the Court should be implemented through the DRP. ${ }^{44}$ The Court decided Plan de Sanchez in $2004,{ }^{45}$ a year after the establishment of the DRP in Guatemala. The Inter-American Court did not entertain the arguments of Guatemala and did not provide any legal reason to justify this position, awarding significant reparations to the hundreds of victims as noted earlier in this article.

The Court might have disregarded such requests from states like Guatemala or Peru, given that the legal arguments put forward by the states were not legally strong - they were more like policy requests - and given the lack of real evidence in those states to corroborate that victims would have access to prompt and effective reparation at the domestic level.

\footnotetext{
${ }^{39}$ Inter-American Court of Human Rights, Garrido v Argentina, judgment on reparations and costs, 27 August 1998.

${ }^{40}$ Inter-American Court of Human Rights, Loayza Tamayo v Peru, judgment on reparations and costs, 27 November 1998.

${ }^{41}$ Inter-American Court of Human Rights, Cantoral Benavides v Peru, reparations and costs, 3 December 2001.

42 Antkowiak (n 1617) 371.

${ }^{43}$ For example, in Castro Castro Prison v Peru the Court did not entertain the allegations, probably because the DRP was in the process of just being set up in the country, as the legal framework had just been adopted and neither the Commission or the legal representatives of the victims referred to it in their pleadings. Final pleadings of the State of Peru in Castro Castro Prison, presented by Oscar Ayzanoa Vigil, State agent, 3 August 2006, 13, available at: http://www.corteidh.or.cr/docs/casos/expedientes/alefi_est.pdf and Inter-American Court on Human Rights, Castro Castro Prison v Peru, judgment on merits, reparations and costs, 25 November 2006, [410-412].

44 "En consecuencia de lo anterior el Estado propone que la ejecución de las medidas de reparación se encausen dentro del Programa Nacional de Resarcimiento, con el apoyo y participación de todos los Organismos del Estado, quienes en el marco de su mandato deberán de implementar las medidas que les correspondan." Presidencia de la Republica, COPREDEH, 21 May 2004, RED-A-28-2004, point 7, 15.

${ }^{45}$ Inter-American Court of Human Rights, Plan de Sanchez Massacre v Guatemala, reparations, (n 5).
} 
The Court reiterates its holistic reparations jurisprudence but DRPs influence amounts ordered as compensation

During this period (around 2010), the Court began to adjudicate on reparations with more caution by taking into account states' views on DRPs. It did not fully defer to states DRPs to provide reparation but began to consider forms to reconcile its reparation standards with those of the DRPs at stake. The option was to reduce the amounts ordered as compensation for material damages. The Court arrived at this position without touching upon its own substantive standards on compensation, as it based its arguments on the lack or scarcity of evidence to prove material damage.

After Plan de Sanchez, the Court heard the case of Chitay Nech in $2010,{ }^{46}$ concerning the lack of investigation into the disappearance, in 1981, of Florencio Chitay, an indigenous leader. The Court asked Guatemala to provide it with information about its DRP. Guatemala sent information to the Court but also requested that the Court award reparation through its DRP. ${ }^{47}$ The legal representatives of the victims argued that Guatemala's DRP was not an effective remedy to obtain redress and that the standards it used were below those established by the Inter-American jurisprudence. ${ }^{48}$

While the Court appears not to have been persuaded that victims would obtain adequate, prompt and effective reparation through Guatemala's DRP, it attempted to reconcile its own jurisprudence with that of Guatemala's DRP in relation to compensation. Indeed, after weighing the evidence on compensation claims presented by the legal representatives of the victims and the state, the Court argued that there was a lack of evidence to support certain claims, or that evidence was presented outside the right procedural opportunity. As a consequence, the Court lowered the amount of money ordered as compensation. For example, in relation to loss of earnings (pecuniary damages), the legal representatives of the victims first requested $\$ 185,000$ in their brief of motions and pleadings, and $\$ 497,310$ in their final pleadings, but failed to provide adequate supporting evidence. The state considered that only $\$ 23,479.32$ was owed as loss of earnings, based on the work of an expert. The Court resolved this conflict, awarding $\$ 75,000$ based on equity. ${ }^{49}$

While the lack of evidence can arguably explain the approach of the Court to loss of earnings, contrasting this case with the amount of money received for loss of earnings in other cases against the same state, such as Bamaca Velasquez, does not necessarily stand legal scrutiny. Bamaca was a guerrilla fighter in Guatemala who was subjected to an enforced disappearance by state authorities in March 1992. He was awarded $\$ 100,000$ for loss of earnings in 2000, 8 years earlier than Chitay Nech. ${ }^{5}$ Importantly, in Bamaca as opposed to Chitay, the Court applied a very flexible approach to evidence as it recognised that after the peace accords were

\footnotetext{
${ }^{46}$ Inter-American Court of Human Rights, Chitay Nech et al. $v$ Guatemala, judgment on Preliminary objections, merits, reparations and costs, 25 May 2010.

${ }^{47}$ Presidencia de la Republica, Comisión Presidencial Coordinadora de la Política del Ejecutivo en Materia de Derechos Humanos COPEDEH, Alegatos Finales del Estado de Guatemala dentro del Caso 12.599 Florencio Chitay vs. Guatemala, Presentado ante la Honorable Corte Interamericana de Derechos Humanos, 3 de marzo de 2010, p. 9-10.

${ }^{48}$ Alegatos finales de las víctimas, Chitay Nech v Guatemala, p. 000855-000857.

${ }^{49}$ Ibid, [267-272].

${ }^{50}$ Inter-American Court of Human Rights, Bamaca Velasquez v Guatemala, judgment on reparations and legal costs, 22 February 2002 [51b].
} 
signed in Guatemala, it was not possible to establish with certainty the jobs or salaries that Bamaca would have had, and awarded compensation for loss of earnings based on equity. ${ }^{51}$

In a similar vein, in the case of Rio Negro Massacres $v$ Guatemala, ${ }^{52}$ concerning five massacres that took place between 1980 and 1982 and various other human rights violations, Guatemala claimed that some of the victims had received reparation through the DRP and that it could pay reparations to all of them through the same route. ${ }^{53}$ The legal representatives of the victims acknowledged that some of them had received payment but considered that such redress was not adequate. ${ }^{54}$ The Court considered that any money paid through Guatemala's DRPs should be subtracted from the amounts it would order, and that the state should provide evidence of the effective delivery of such monies to the victims. ${ }^{55}$

The Court defers decisions on reparation to states with strong DRPs but qualifies the orders

From 2013 onwards, the Court began to defer decisions on reparation to states, not as a result of the natural evolution of its jurisprudence, but more as a direct consequence of the DRPs that were at stake and, probably, also as a result of the crisis the Inter-American System was having with the so called strengthening process.

Worldwide and in the transitional justice literature more broadly, the DRPs of Chile and Colombia are seen as examples of ambitious programmes aimed at offering redress to victims with a significant degree of effectiveness. Therefore, challenges to these DRPs required a different approach by the Court. Indeed, The Court applied the subsidiarity principle in relation to these DRPs, but qualified its deference to the domestic system.

In relation to Chile, the case of Garcia Lucero and others ${ }^{56}$ is illustrative of this as the Court avoided dealing with Chile's DRP, appealing to jurisdiction issues and the subsidiarity principle. This case concerns the denial of justice and lack of adequate reparation for Mr. Garcia Lucero, a torture survivor in exile, and his family. The lawyers of the alleged victims claimed that Chile's DRP did not allow Mr. Lucero or his family to enjoy the various forms of redress he was entitled to as he was away from Chile, and measures such as access to the health system were not provided outside of the country. It was also alleged that the denial of justice had caused him and his family suffering that should be redressed. ${ }^{57}$

The Court sidestepped dealing with the DRP by stating that it did not have jurisdiction ratione temporis to deal with reparations for acts of torture, as Chile had not ratified the Convention or accepted the Court's jurisdiction when the facts of the case took place. More importantly, according to the Court, the intrinsic connection that exists between the right to reparation and the right to an adequate and effective remedy obliged the tribunal to examine whether Mr. Lucero had access to adequate and effective domestic remedies to challenge the DRP. The Court held that it had not been given enough evidence to find that he did not have

\footnotetext{
51 Ibid.

${ }^{52}$ Inter-American Court of Human Rights, Rio Negro Massacres $v$ Guatemala, judgment on preliminary objections, merits, reparations and costs, 4 September 2012.

${ }^{53}$ Ibid, [299].

${ }^{54}$ Ibid, [298].

55 Ibid, [304].

${ }^{56}$ Inter-American Court of Human Rights, Garcia Lucero and Others $v$ Chile, judgment on preliminary objections, merits and reparations, 26 August 2013.

57 Ibid, [2].
} 
access to adequate or effective remedies, and relied on the subsidiarity principle to consider that it was barred from knowing about this allegation, as domestic remedies in this regard had not been exhausted. ${ }^{58}$ This case shows the Court using three different legal means to avoid dealing with the DRP: jurisdiction ratione temporis, the principle of subsidiarity, and evidentiary standards.

Nevertheless, the Court considered that Chile failed to start an investigation motu propio as soon as it knew that Mr. Lucero had been a victim of torture, and awarded $£ 20,000$ (as he was in the UK) as compensation for non-material damages in relation to this. ${ }^{59}$ Importantly, while the Court did not directly address the legality of Chile's DRP in application of the subsidiarity principle, the Court exhorted Chile to provide a reasonable amount of compensation to Mr. Lucero for rehabilitation purposes, even if such rehabilitation had to do with harm caused as a result of the torture he suffered. The Court did not establish the amount of money to be paid to Mr. Lucero. It deferred this to Chile. However, it set a standard; that it should be a 'reasonable' amount of money. This illustrates an important jurisprudential turn in the award of reparations, one that uses diplomatic means to provide redress to victims without openly challenging a domestic reparations policy. Instead, the Court appealed to the good will of the state to provide redress for harm that the Court considered should be redressed.

A similar treatment is visible in the case of Colombia. So far the Inter-American Court has decided just one case where Colombia's DRP is at stake, that of Operation Genesis. ${ }^{60}$ The case relates to a military operation carried out in the area of the Salaquí and Truando rivers between 24 and 27 February 1997, which resulted in the death of Marino López Mena and the displacement of hundreds of members of the Afro-descendants communities of the Cacarica river. In this case the Court identified 372 victims, of whom 341 were displaced persons. $^{61}$

In Genesis, a discussion took place about 'the sufficiency of the measures included in the Victims and Land Restitution Law to make reparation to the victims, ${ }^{62}$ and Colombia argued that 'the administrative reparation programme constitutes an effective remedy for the fulfilment of the right to reparation, which needs to be exhausted before going to the InterAmerican System'. ${ }^{63}$ In contrast to the Guatemalan cases, and similar to the Chilean position in Garcia Lucero et al, the Court took due account of the DRP but ordered additional reparations or qualified its views when it considered it appropriate. For example, in relation to rehabilitation, the Court ordered Colombia to provide it through its DRP, but qualified the order by stating that 'victims should be given immediate and priority access to health care services, regardless of the corresponding time frames established by domestic law, avoiding obstacles of any kind'. ${ }^{64}$ (italics outside original text)

\footnotetext{
${ }^{58}$ Ibid, [185-206].

${ }^{59}$ Ibid, [246].

${ }^{60}$ Inter-American Court of Human Rights, Case of the Afro-Descendant Communities Displaced from the Cacarica River Basin (Operation Genesis) v Colombia, judgment on preliminary exceptions, merits, reparations and costs, 20 November 2013.

${ }^{61}$ Ibid, [431].

62 Ibid, [414].

${ }^{63}$ Republica de Colombia, Alegatos Finales, Marino López y Otros (Operacion Genesis), March 2013, [469].

${ }^{64}$ Inter-American Court of Human Rights (n 6063) 453 (emphasis added).
} 
Similar treatment was given to other forms of reparation, such as compensation, ${ }^{65}$ restitution and guarantees of non-repetition. The Court ordered them through Colombia's DRP, and ordered that victims should have access to such forms of reparation within a year of the notification of the judgment, at the very latest. ${ }^{66}$ Other cases involving Chilean and Colombian DRPs have made their way to the Inter-American System and an important case Yarce and Others $v$ Colombia - will be decided by the Court in the near future. ${ }^{67}$ The legal representatives of the victims have challenged the effectiveness of Colombia's DRP to provide reparation to victims. The decision the Court makes will either reiterate its approach in Genesis to hard cases where strong DRPs are involved, or will revise this precedent. It is unfortunate that at the time of publication of this article the judgment in this case is not yet known.

Tenorio Roca and Others $v$ Peru is the most recent case decided by the Court where a DRP is at stake. ${ }^{68}$ Peru argued that the Court should take its DRP into account when ordering reparations for the victims, and provided information to the tribunal about its programme, which is known as PIR. According to Peru, most of the victims in the case were beneficiaries of its PIR domestically. ${ }^{69}$ The Court considered that while some of them were, in theory, beneficiaries of the programme, the Court did not have enough evidence to show that they had received effective reparation according to PIR standards. As a result, the Court ordered reparation for the victims in the case, following its Inter-American standards. ${ }^{70}$ Importantly, when dealing with scholarships for the victims as a form of satisfaction, the Court took note that the PIR allows certain beneficiaries of reparation to transfer their right to education to a next of kin, ordering Peru to allow this for the children of the disappeared, or to allow them to transfer it to one of the grandchildren of the disappeared. ${ }^{71}$

The case of Roca and Others is different to Garcia Lucero or Genesis in that it does not show a direct appeal to the subsidiarity principle. Nevertheless, it shows that if Peru had provided the Court with enough evidence to show that victims were truly having access to effective reparation, the Court would have abstained from awarding reparation and most probably would have referred to the subsidiarity principle. Indeed, what was crucial for the Court in this case was whether the PIR was effective, but the Court did not question the standards of the programme. Furthermore, the Court applied the standard of the PIR to scholarships, even if in the specific case it widened the application of the rule to other members of the family.

\footnotetext{
${ }^{65}$ When the Court dealt with compensation it distinguished, without providing reasons, between the next of kin of Marino, who had been killed, and the displaced Afro-descendants. As a consequence, it awarded nonpecuniary damages different to those of the DRP to his next of kin but not to the Afro-descendants, claiming that the violations they suffered were different to those covered under the DRP. Ibid, [476].

${ }^{66}$ Ibid, [461].

${ }^{67}$ This case concerns serious human rights violations suffered by five women who were human rights defenders and leaders in Comuna 13, in Medellin (Colombia). One of them was killed, and the others were threatened and displaced. All of these violations took place at a time of intensified military and paramilitary operation in the region. The case arrived before the Court on 3 June 2014 and is to be decided. The hearing took place more than a year ago in June 2015, and a key issue at stake was the effectiveness of the DRP in Colombia. Various expert opinions and amicus curiae were presented addressing this issue.

${ }^{68}$ Inter-American Court of Human Rights, Tenorio Roca and Others $v$ Peru, judgment on preliminary

exceptions, merits, reparation and costs, 22 June 2016.

${ }^{69}$ Ibid, [277-278].

${ }^{70}$ Ibid, [279-280, 284].

${ }^{71}$ Ibid, [296-298].
} 
The Court decides on reparation taking into account if the violation found to have taken place is redressed by the DRP

Another important development in the recent jurisprudence of the Court is to take into account the nature of the human rights violation it has found and to consider whether such violation is covered by the DRP or not. In Maldonado Vargas $v$ Chile, ${ }^{72}$ for example, which concerned the denial of justice during Pinochet's dictatorship and during the return to democracy for twelve people who were tortured and prosecuted in violation of various due process guarantees, the legal representatives of the victims requested reparation for nonpecuniary harm, regardless of the DRP, as a consequence of the lack of a due diligence investigation and the harm caused to the victims' honour and dignity. ${ }^{73}$ Chile argued that the principle of subsidiarity should apply, as the victims in the case were beneficiaries of its DRP. ${ }^{74}$ Both the Commission and the Court considered that, while the victims had received reparations under the DRP, they were entitled to them for different human rights violations than the violations under consideration by the Court, ${ }^{75}$ namely the right to a fair trial and judicial guarantees. The Court ordered pecuniary damages for the twelve victims. Four of them received $\$ 30,000$ each, the other eight victims being awarded $\$ 25,000$ each. $^{76}$

\section{What are the consequences of this jurisprudential turn?}

There are various legal and institutional consequences of the shift in the jurisprudence of the Inter-American Court in relation to reparations and DRPs.

\section{Subsidiarity is transforming the standards of the Court}

From a legal point of view, the primacy of subsidiarity is changing the content and scope of the substantive principles on reparations that have been crafted by the Inter-American Court of Human Rights. While the concept of subsidiarity is central to international human rights 'it is not a rigid or precise one, and it is characterised by internal tensions and inherent paradoxes that need to be identified' ${ }^{77}$ The application of subsidiarity to the coexistence of different standards on reparations at the international and domestic level shows some of these paradoxes and calls for ways to resolve them. As a structural principle of human rights law, subsidiarity is nothing new. However, the way human rights courts such as the InterAmerican Court have changed their approach to it over time is significant. Indeed, the InterAmerican Court is relying on subsidiarity more and more to avoid what states could consider undue interference or intervention with their domestic affairs. For decades, the InterAmerican Court did not apply the principle in toto or blindly to deal with reparations or to adjudicate on other matters. Instead, the Court crafted important rules that would allow the principle to apply but not to the detriment of human rights protection. ${ }^{78}$

\footnotetext{
${ }^{72}$ Inter-American Court of Human Rights, Omar Humberto Maldonado Vargas et al. $v$ Chile, judgment on the merits, reparations and costs, 2 September 2015.

${ }^{73}$ Ibid, [173].

74 Ibid.

${ }^{75}$ Ibid, [175].

${ }^{76}$ Ibid, [178-179].

${ }^{77}$ Paolo Carozza, 'Subsidiarity as a structural principle of international human rights law' (2003) 97 American Journal of International Law 38.

${ }^{78}$ Inter-American Court of Human Rights, Velasquez Rodriguez v Honduras, preliminary objections, 26 June 1987, [93].
} 
From its first judgment, the Court also set important limits to the principle of subsidiarity in relation to reparations. As illustrated in Velasquez Rodriguez, Honduras also appealed to subsidiarity when putting forward its arguments on reparation. Honduras argued that, while the Court could order compensation to redress the harm caused to the next of kin of Manfredo Velasquez, the Court had to calculate the amount of such compensation by applying Honduras' laws on the matter. ${ }^{79}$ The Court noted that the American Convention:

'does not condition the orders of the Court to the effectiveness of the reparation instruments available at the domestic level [...] Therefore, [reparation] is not established based on the defects, imperfections or problems of national law but functions independently of it. ${ }^{, 80}$

As this precedent notes, the Court exercised full jurisdiction over the award of reparations and did not entertain arguments on subsidiarity.

Despite this precedent, this article shows that while the Court is trying to uphold its own reparation standards, their content and scope is changing as it tries to defer important decisions on reparation to states. For example, cases like Genesis ${ }^{81}$ where the Court upholds the view that victims who have suffered such terrible violations are entitled to rehabilitation, show that the Court is not yet ready to depart from the standard, but by allowing Colombia to provide rehabilitation through its own DRP it is transforming the scope and reach of the right to rehabilitation. With Genesis, the Court did not make any reference to the obligation of Colombia to provide rehabilitation that included specialised tests and free medicines, ${ }^{82}$ something that was present in other judgments where the Court upheld not only the standard, but also its usual understanding of the right to rehabilitation. ${ }^{83}$ Something similar happens with compensation awards. The Court continues to recognise that such violations merit pecuniary and non-pecuniary damages, but quantification of such compensation has changed as the awards have been lowered, as can be seen in the cases of Guatemala, or have been ordered through DRPs, such as the Colombian case which provided victims with less compensation than that previously determined by the Inter-American Court.

\section{The jurisprudential turn is creating legal uncertainty as it lacks adequate legal reasoning}

The jurisprudential change and the various shifts seen in the jurisprudence of the Court also generate legal uncertainty among the parties to the litigation as to which substantive and procedural rules apply to DRPs when litigating a case before the IAHRS. A constant in all the cases where the Court has dealt with DRPs is the lack of reasoning and adequate assessment of evidence when considering domestic reparation programmes. The Court basically decides whether or not to take DRPs into account and awards reparations accordingly, but has not so far properly assessed whether the legal standards of those DRPs are in line with its jurisprudence on the matter, or with international law. Nevertheless, both in Garcia Lucero

\footnotetext{
${ }^{79}$ Inter-American Court of Human Rights, Velasquez Rodriguez v Honduras, judgment on reparations, 21 July 1989, paras. 44-55.

${ }^{80}$ Ibid, paras. 28-30.

${ }^{81}$ Inter-American Court, Genesis (n 6063).

82 Ibid, [453\}.

${ }^{83}$ Inter-American Court of Human Rights, Massacre of Santo Domingo v Colombia, judgment on preliminary exceptions, merits and reparations, 30 November 2012 [309].
} 
and Operation Genesis the Court appears to have laid down criteria to test the legality of DRPs, but failed to apply such criteria to the facts of the cases before it.

In Garcia Lucero the Court considered that any mechanisms at the domestic level intended to provide reparation should be assessed by the Court, in light of the obligations of the state on the matter, and bearing in mind three requirements: whether the mechanisms were objective, whether they were reasonable, and whether they were effective. ${ }^{84}$ However, the Court failed to define each of these requirements and to apply them to Chile, limiting itself to considering that it had already praised its DRP in Almonacid Arellano. ${ }^{85}$ In Genesis, the Court established new criteria, referring in particular to compensation for non-pecuniary damages, but yet again failed to apply the criteria to the case. The Court identified the following non-exhaustive requirements:

a) They should have legitimacy, meaning that victims must have been consulted and should have given participation in the process;

b) They should have been adopted in good faith;

c) They should permit certain degree of social inclusion;

d) Any pecuniary measures they include should be reasonable and proportionate;

e) They must justify providing reparations by group rather than by individual, and how money is divided between members of the family; and

f) They must take into account gender and other relevant aspects. ${ }^{86}$

It is unclear why the Court has failed to define and apply the criteria it has crafted in its judgments to the DRPs in question. Its requirements, that reparations mechanisms should be objective, reasonable and effective, need to be fleshed out following International Law standards on reparation and those of the Inter-American Court. In the case of Garcia Lucero the Court did not apply these requirements, probably because it argued that domestic remedies were not exhausted in relation to the DRP, but this was perhaps the argument that was needed to avoid having to examine the DRP's legal validity. In Genesis, given that various elements of the DRP were at stake, the Court should have instead followed the criteria set up in Garcia Lucero. It should have carried out a careful analysis of the DRP, given that it had important evidence to hand, yet once again it failed to apply such criteria. Nevertheless, the Court went further and established new criteria to deal with compensation in DRPs, but once again failed to apply it to the case.

The other relevant legal change that generates legal uncertainty concerns the evidence that is needed to prove the harm that has been suffered as a result of such violations. While the Court used to take a flexible approach to the subject by shifting the burden of proof or lowering the standard of evidence when DRPs were at stake, it appears to be changing its

\footnotetext{
${ }^{84}$ The Court establishes these requirements for the first time in its judgment Cepeda $v$ Colombia where tensions between reparations through the judiciary and those to be awarded by the Court were at stake. The first time the Court refers to these standards in relation to DRPs is Garcia Lucero.

${ }^{85}$ Inter-American Court, Almonacid (n 30).

${ }^{86}$ Inter-American Court of Human Rights, Genesis (n $\underline{6063}$ ) [469-476].
} 
approach, probably to justify changes in the content of its standards, or in its awards on reparations. However, given that the changes are taking place from case to case, it is not always possible to conclude which rules or tests the Court will apply to evidentiary rules, making it very difficult to know, as a litigant before the Court, which arguments should be put forward or the evidence that could be presented. This is particularly dangerous in relation to cases that have been pending in the system for several years, as they have, most probably, been litigated under the old approach to reparations, and arrived to the Commission more than 8 years ago.

\section{It hinders the ability of victims to obtain adequate, prompt and effective reparation}

Another consequence of this jurisprudential shift is that it hinders the ability of victims to obtain adequate, prompt and effective redress for the harm suffered. Either they will obtain less compensation than they would have obtained a decade ago from the Court or, as a consequence of deferring to DRPs to redress such violations, the role of the Inter-American Court will be diminished and victims will be back to square one in terms of the protection of their rights. Indeed, victims that get a case to the Court will have had to wait for at least eight years for the Court to decide the case, and after that time they may be told by the Court that they have to return to the domestic system that, in their view, has already failed them. Therefore, subsidiarity on reparations creates a tension with the objectives sought by a complementary system under international human rights law. Certainly, the Court does not lose jurisdiction over the case once it has decided on reparation, as the tribunal continues to monitor compliance with its orders through a more informal process. However, through this process the Court will only monitor compliance and will not be able to challenge a DRP. This opportunity, nevertheless, could be used in important ways to ensure that subsidiarity translates into better implementation, but there are limits to what the Court can do and achieve when monitoring compliance with its orders. ${ }^{87}$

There are also consequences for the institutional design of the Inter-American System. The Inter-American System is composed of two institutions, both with jurisdiction over alleged human rights violations: the Commission and the Court. They work in different ways. However, in relation to those states that have ratified the American Convention and have expressly accepted the jurisdiction of the Court, the System has been designed bearing in mind that, if the domestic system is unwilling or unable to remedy violations, then the complementary system on individual petitions of the Inter-American System (both before the Commission and the Court) could be triggered. But given that the Americas System is twotier, meaning that states are given an additional opportunity at the Commission stage to resolve the violations without the Court having to adjudicate on them, if a case does reach the Court it is because, in the view of the Commission, the state failed to implement its recommendation in a timely manner. Therefore, the state failed to remedy the violations. In such a context, justifying the appeal to subsidiarity by the Court is even harder, and this is something the Court should bear in mind when adjudicating on DRPs as the state would have failed not once but twice in fulfilling the right to reparation.

\section{Conclusions}

\footnotetext{
${ }^{87}$ Resolución de la Corte Interamericana de Derechos Humanos, Supervisión de Cumplimiento de Sentencia Casos Masacres de Rio Negro y Gudiel Alvarez y Otros, 21 August 2014, [2c].
} 
This article has sought to make visible an important jurisprudential shift in the work of the Inter-American Court that threatens one of its most ground breaking contributions to Human Rights Law: its reparations jurisprudence.

The Inter-American System is changing. Victims are more than ever aware that they have a right to adequate, prompt and effective reparation, and they are demanding it. States are resisting these claims, particularly when transitional justice efforts such as DPRs are at stake. But as this article shows, change is never linear. In the case of reparations, the IAHRS and in particular the Court, took two steps forward by crafting substantive and procedural principles to deal with redress in order to dignify victims. This contribution to International Human Rights Law has been widely recognised and has benefited many victims across the region, and internationally, who have suffered gross human rights violations as a result of repression or armed conflict. However, the Court's treatment of subsidiarity and its changing jurisprudence on DRPs constitutes a step back as they are transforming its Inter-American Standards, substantive and procedural, on reparation without proper legal argument. The current approach of the Court does not stand serious legal scrutiny, as it fails to provide reasonable grounds for its views on DRPs. Furthermore, there is no evidence to-date to illustrate that this jurisprudential shift works in favour of victims by allowing them to get adequate, prompt and effective reparation.

The aim of this article has not been to criticise the work of the Court. On the contrary, it considers that when coexistence in relation to reparations is at stake, it is essential to find ways to harmonise standards and to make reparations accessible to victims in a prompt, adequate, and effective manner as coexistence does not always work in favour of victims and can do more harm than good. Therefore, the Court is pursuing a noble goal, but could and should deal with DRP cases differently.

The Court is not simply applying blind deference to domestic systems, as it does qualify its approach and has been able to take different positions in relation to different states, but the reasons behind the differential treatment between cases is not clear. It appears that the Court is moving towards qualified deference, meaning that it is giving control to OAS member states over reparations through their DRPs if they appear to be effective and robust, as is the case of DRPs in Chile or Colombia. In such cases the Court applies the subsidiarity principle but qualifies the modes of compliance with the order it gives (Genesis or Garcia Lucero). In relation to states where the effectiveness of DRPs could be questioned, the Court appears to be more willing to reconcile its standards with those of DRPs, or to explore whether such programmes do in fact redress the violations it has found and whether they are truly effective (Chitay Nech, Maldonado, and Tenorio Roca).

Nevertheless, the Court is yet to articulate proper legal arguments and address a crucial issue when there is co-existence of regimes, which is whether or not the legal standards applied by DRPs are compatible with international human rights law and with the Court's own jurisprudence. This remains an essential but missing step to achieve harmonisation and to protect the right of victims to obtain adequate, prompt, and effective redress for human rights violations, that states have been unwilling or unable to provide for years. The work for the coming years, then, is for the Court to create a well-grounded legal justification of its approach to reparations in those countries undergoing processes of transitional justice. It may well be that subsidiarity is a necessary legal tool to deal with some DRPs, but even in such 
situations it is essential to provide legal operators (both states and victims) with a reasoned judgment as to why this is the case. Otherwise, legal uncertainty will prevail and will only erode the authority and legitimacy of the Court while sacrificing one of the most valuable rights that victims have: their right to adequate, prompt, and effective reparation. 